\title{
MICROTOPONYMS AS AN IMPORTANT PART OF SLOVENIAN CULTURAL HERITAGE
}

Jožica Škofic

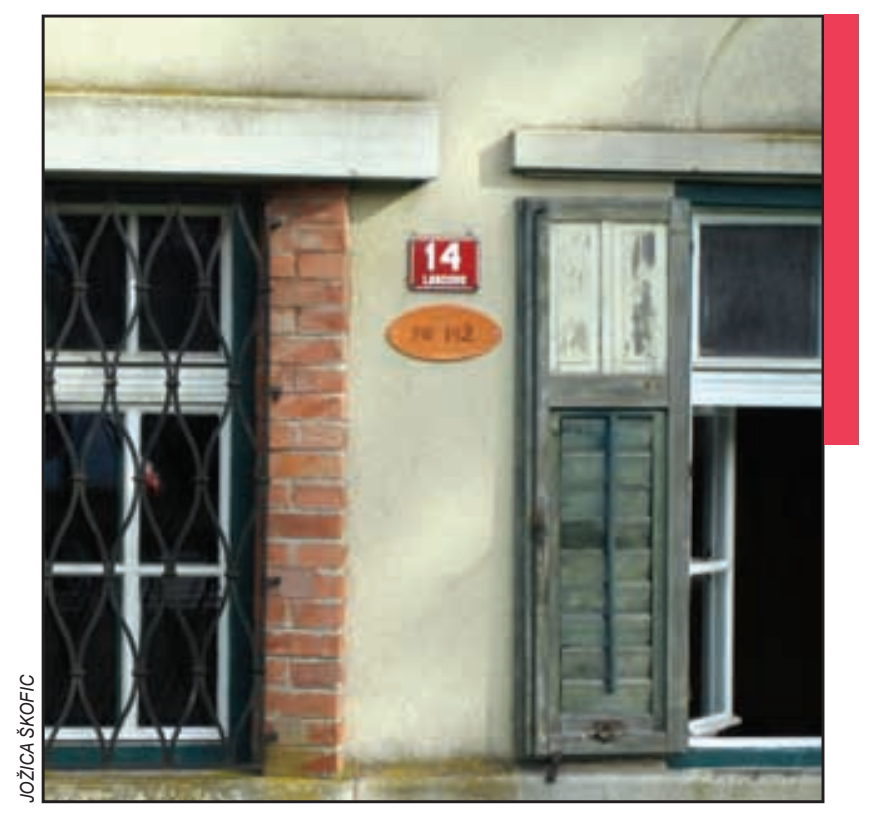

Plaque with the oeconym Pr Pižin Lancovo. 


\section{Microtoponyms as an important part of Slovenian cultural heritage}

DOI: http://dx.doi.org/10.3986/AGS.4670

UDC: $811.163 .6373 .21(497.4)$

COBISS: 1.01

ABSTRACT: This article presents a methodology for data collection and documentation of microtoponyms in the Upper Carniola / Gorenjsko dialect of Slovenian based on visual and audio recordings. Special attention is placed on transcription (phonetic or simplified phonological transcription and standardization), which should be based on a morphological analysis of the toponyms examined. Linguistic analysis and its consideration of the dialect characteristics of toponyms can help reconstruct their naming motivation and origin. The article presents selected toponyms lexicographically and cartographically.

KEY WORDS: microtoponyms, linguistic analysis, standardization of dialect names, orthography, lexicography, geolinguistic presentation of toponyms, Upper Carniola / Gorenjsko dialect, Slovenia

The article was submitted for publication on September $5^{\text {th }}, 2016$.

\section{ADDRESS:}

Jožica Škofic, Ph.D.

Fran Ramovš Institute of the Slovenian Language

Research Center of the Slovenian Academy of Sciences and Arts

Novi trg 4, SI -1000 Ljubljana, Slovenia

E-mail: guzej@zrc-sazu.si 


\section{Introduction}

Slovenia ratified the Convention for the Safeguarding of Intangible Cultural Heritage, adopted by UNESCO in 2003 in Paris, on December 19th, 2007. With this ratification, Slovenia committed itself to protecting oral traditions and vocabulary, including language as a bearer of intangible cultural heritage. From this point of view, dialect forms of microtoponyms in the broad sense (including oeconyms and cadastral toponyms) that are used in everyday life by local people are also an important part of Slovenian cultural heritage.

An oeconym (also known as a house name, farm name, etc.) is a toponym that denotes an occupied or unoccupied house with a street number in a settlement, a farm with or without land, farm outbuildings (e.g., grain mills, sawmills, etc.), or communal village buildings (e.g., a church, rectory, school, inn, fire station, etc.). Oeconyms remain connected to houses and estates even after the original owners move on and may remain unchanged for centuries. A microtoponym in the narrow sense (also known as a cadastral toponym, field name, etc.) is a non-settlement-related toponym in the narrow (toponymic) and wider (geonymic) senses, denoting parts of the land used for cultivating crops or fodder, fields, orchards, vineyards, meadows, pastures, and forests (agronyms); water areas (hydronyms); small slopes and mountains (oronyms); paths; and orientation points (overlooks, signs, wayside crosses, mountain cabins, etc.). They often reflect the geomorphological, historical, biological, geological, and social characteristics of a country, as well as the historical development of the spoken language. People use microtoponyms to designate the space where they live and work, and to make orientation in it easier.

Slovenian oeconyms and microtoponyms are of great interest to linguistics, and so many onomastics articles have been published on this topic in recent years (this article draws upon Šivic-Dular 1988, 2000; Merkù 1993; Furlan, Gložančev and Šivic-Dular 2000; Škofic 2001, 2007, 2009; Keber 2002; Čop 2007; Šekli 2008; Snoj 2009). In recent years, many projects have also been carried out to collect oeconyms and microtoponyms. »Their collection and research was unsystematic, spatially dispersed, and used varying research methodologies. Regarding the researchers' profiles, these types of issues were at the center of interest of not only professionals from various scholarly disciplines, but also individual amateur researchers" (Klinar and Geršič 2014, 414).

This article presents oeconyms that were collected by RAGOR (the Northwest Upper Carniola Development Agency) in cooperation with the author of this article in projects such as "Nomen vulgare « and others (Klinar 2013) and in the cross-border project »FLU-LED - Kulturni portal ledinskih in hišnih imen« (The Cultural Portal of Microtoponyms and Oeconyms), which is being carried out as part of the EU's 2007-2013 Slovenia-Austria Operational Program in the border area of southern Carinthia and Upper Carniola (Klinar et al. 2012; Internet 1). In this project, the methodology for recording microtoponyms was set up and presented in the volume Metode zbiranja hišnih in ledinskih imen (Methods for Collecting Oeconyms and Microtoponyms; Klinar et al. 2012). The results were published in special booklets titled Kako se pri vas reče? (What's the Name of Your House?; Klinar 2011; Škofic 2011), on printed and e-maps of the FLU-LED project (Klinar and Škofic 2015a, 2015b, 2015c) and also on some internet portals (for more about collecting and marking oeconyms in these projects, see Klinar and Geršič 2014).



Figure 1: Booklets in the series Kako se pri vas reče? (What's the Name of Your House?). 


\section{Methods and transcription}

Not only contemporary dialect information from local people but also historical sources are important for collecting and recording oeconyms and microtoponyms: "An overview of written sources is a good basis for fieldwork, in which the selection of good informants is vital« (Klinar and Geršič 2014, 415).

Because Slovenian is an inflective language, the nouns and adjectives in a toponym must be documented in the various forms they appear in; namely, in the nominative case, the bare genitive (as a subject in negative clauses or as a negated direct object), and in the locative, accusative, genitive with a preposition (corresponding to where at? where to? where from?). Names that are prepositional phrases must be recorded as well.

In the next stage of research (transcribing the material collected), the collaboration of linguists is also of great importance because they can offer advice on how to design a simplified dialect transcription that can be used by local people and non-linguists, even though linguists and dialectologists need more precise information about the pronunciation of oeconyms and microtoponyms. In Slovenian dialectology (and in this article) a standardized Slovenian phonetic transcription is used (see Kenda-Jež 2016) to mark all qualitative and quantitative features of the spoken language and its phonemes (e.g., Par Matíjouc, Matíyjoučcou vò: $x$ ). Unlike IPA transcription, this simplified transcription uses only the Slovenian alphabet, a special letter for schwa (ə), three diacritics to mark accent (acute, grave, and circumflex), and the IPA length mark. Careful consideration is needed for deciding how to write or mark accents, the length and quality of accented vowels, syncopated and reduced vowels, and semivowels. One should also consider other dialect developments of vowels and consonants, means of preserving morphological word-formation, and syntactic features as preserved in names (such as Par Matijovc, Matijovčov vóh, to repeat the same two examples).

A third possibility for writing these names is to standardize them on the basis of careful linguistic (morphonological) analysis; for example, Pri Matijevcu and Matijevčev log (to repeat the same two examples). In Slovenian onomastics, the practice is to standardize oeconyms only at the phonetic and orthographic levels (because people can identify with them easily), whereas microtoponyms and other toponyms used by the general public are standardized in line with etymological and historical principles (e.g., [špá:nove

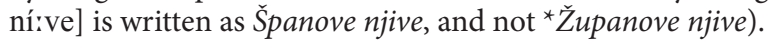

\section{Linguistic analysis and presentation}

\subsection{The motivation, origin, and structure of oeconyms and microtoponyms}

Oeconyms often have one of the following naming motivations: the surname of the first owner (Klinar, Potočnik, etc.), the first name of the first owner (Balont »Valentin «, Jernač »Jernej«, Matevžek »Matej/Matevž«, Šema "Simon", Jerca "Jera, Gertruda", etc.), a nickname of the first owner, which may have arisen from characteristics of the property (Vretena "spindle«, Loden »shop (cf. Germ. Laden) «, Oštarija »inn (cf. It. osteria) «, etc.), typical foods (Štrukelj »dumpling «, Klobasa »sausage«, Kašar "porridge«, Zabela »butter, fat, lard «, Prata »smoked pork«, etc.), typical plants (Smrekar »spruce«, Podlipnik »linden«, Žavbla »sage«, etc.), typical animals (Volk»wolf», Komar »mosquito«, Zajček»rabbit«, Muren »cricket«, Miška »mouse«, etc.), physical characteristics of the owner (Kobala »bowlegged «, Ta dolgi »long«, etc.), psychological characteristics of the owner (Fovšaritnica »envious«, Alelojovka »alleluia«, Tajč »German (cf. Germ. Deutsch)«, etc.), or the geographical origin of the owner (Kropar »Kropa ", Dražgošan "Dražgoše«, Korošček "Carinthia", Bohinjec »Bohinj «, Rezijan »Resia «, Amerikanc »America «, etc.). Oeconyms are also frequent that have arisen from the profession of the owner (Kovač »blacksmith «, Šuštar »shoemaker «, Žnidar »tailor «, Mlinar »miller«, Fadajinka »noodle-maker«, Skirar »ax-maker«, etc.), the social status of the owner (Špan »mayor«, etc.), the position of the house (Na Skalci »rock«, Podgradovc »castle», Mostar »bridge«, etc.), the function of the house (Mežnarija »sexton", Šola »school«, etc.), and so on.

Microtoponyms often have one of the following naming motivations: position (Zgornji/Srednji/Spodnji konec »upper/middle/lower part «, Za krajem »at the end «, etc.), geomorphological characteristics (Čelce "forehead», Ojstra peč »sharp rock«, Zjavka »cave«, Galerije »gallery«, Frtala »to spin«, Vilice »fork«, Podplatasta skala »rock like a sole«, etc.), typical color (Črni vrh »black peak«, Črni potok»black stream«, etc.), plant names (Bukovlje »beech", Pod Lipo »linden«, Brezovica »birch«, Hrinovec »horseradish", etc.), animal names 
(Junčevica »steer «, Jagnjevica »lamb«, Petelinovec »rooster «, Konjski britof »horse boneyard «, Gamsov skret »chamois dung area«, Medvehka »bear«, etc.), structures (Zgornji bajer »upper pond «, Za mlinom »mill«, Skakalnica »ski jump«, Pri stogu »hayrack«, Pretvornik»convertor», Kapelica »wayside shrine«, Plac »market square«, Mala gasa »little alley«, etc.), personal names (Na Jernaškem »ernej«, Pri Marijici »Marija«, Petrovec »Peter «, Boštjanov bošt »Boštjan«, Mihovčev strmec »Miha«, Martinček »Martin«), owned properties (Koničarjev travnik »Koničar's meadow «, Klofčarjev graben »Klofčar's ravine», etc.), and people’s activity (Za Dolgo njivo »long field «, Streljavnica »to shoot «, Dekliški tomf »maiden pool«, Mili pogled »gentle view«, Tam, kjer je ta mrtvi ta živega ubil »Where the dead one killed the living one«, Žegnan studenec »blessed well/spring «, etc.).

As can be seen, many of these names are of Slavic origin, but many of them are loanwords from various contact languages (mostly German and Italian). Oeconyms and microtoponyms also have different structures because these "are mainly one-word toponyms with masculine, feminine, or neuter gender, in the singular or plural. Quite common are also noun phrases with left attributes that specify possession, position, and other characteristics of the places named. Special attention is given to prepositional and compound names, which are interesting because of their polymorphic structure; such toponyms are often in a process of formation (nomina propria in statu nascendi »developing proper names «), and so these names often show an intermediate stage between common and proper name, pointing to their false propriety (pseudo-propriety or proto-propriety)« (Škofic 2016, 220). Toponyms with more complex structures (such as a sentence) are quite rare.

\subsection{Lexicographic and cartographic presentation of oeconyms}

This subsection presents the microstructure of entries in the dictionary of Slovenian dialect oeconyms (Škofic 2014).

Although many names have the same root, it is necessary to present not only the root but also all derivative forms with various suffixes in their Proto-Slavic forms.

The standardized form of an oeconym (formed on the basis of morphological analysis, in which the phonetically abstracted name, following the phonetic rules of the dialect, is followed by its Proto-Slavic equivalent and by its derivational predecessors or sources from foreign languages) is followed by the symbol . and an identification of the name (i.e., places/villages with house numbers) with the dialect form of the oeconym accented and standardized (in square brackets). This is followed by the standardized and dialect names for the male and female head of the property (following the symbols $\sigma^{\prime \prime}$ and $O$ ) in the nominative and genitive as well as the corresponding adjective in standardized and dialect variants (in the masculine, feminine, and neuter forms). Each identification unit may also have a documentary section (after the symbol $*$ ), stating the name in its historical sources: FK = the Franciscan cadaster (Protocols ... 1823-1896); SA = Status animarum (parish family records; Parish ... 1750-1950; Škofic 2013, 2014).

kovač- $\Rightarrow$ Kovač, Kovaček, Kovačevec, Kovačič, Kovačijovec, Kovačnica $\leftarrow$ *kov-a-č-b (»smith«) *kov-a-ti kuj-Q »to forge«

Pri Kovaču $<*$ pri $»$ at « $+* k o v-a-\check{c}-b$

- HN Bašelj 14: Pri Kováču [pər ková:č], ơ Kováč [ková:č -a], o Kovačíca [kovačíica -e], adj. Kováčov [ková:čou -ova -oun] FK 1827 Kovatsch, SA 1771 Kovazh, SA 1880 Kovač

- HN Begunje na Gorenjskem 109: Pri Kováču [pər ková:č], ơ Kováč [ková:č -a], O Kovačíca [kovačíca -e], adj. Kováčov [ková:čou -ova -ou] * SA 1750-1859 Kovazh, SA 1750-1873 Kovazh

- HN Bistrica (Naklo) 16: Pri Kováču [pər ková:č], ơ Kovàč [ko'vəč ková:ča], o Kovačíca [kovačíca-e], adj. Kováčov [ková:čou -ova -oun] * I

- HN Bled, hamlet of Rečica, Triglavska cesta 5: Pri Kováču [pər ková:čo], ơ Kováč [ková:č -a], O Kovačíca [kovačíca -e], adj. Kováčov [ková:čou -ova -oun] * I

- HN Bodešče 22: Pri Kováču [pər ková:č], ơ Kováč [ková:č -a], O Kovačíca [kovačíca -e], adj. Kováčov [kováčou -ova -ou]] * FK 1827 Kovatsch, SA 1900-1910 Kovač

- HN Bohinjska Bela 118: Pri Kováču [pər ková:č], ơ Kováč [ková:č -a], O Kovačíca [kovačíca -e], adj. Kováčov [ková:čou -ova -oun] * SA 1900-1910 Kovač 
- HN Bohinjska Bela 24: Pri Kováču [pər ková:č], ơ Kováč [ková:č -a], o Kovačíca [kovačíca -e], adj. Kováčov [ková:čou -ova -ou] * FK 1827 Kovatsch, SA 1900-1910 Kovač

- HN Bohinjska Češnjica 73: Pri Kováču [pər ková:čo], ơ Kováč [ková:č -a], O Kovačíca [kovačíca -e], adj. Kováčov [ková:čou -ova -ou] * FK 1827 Kovazh, SA 1831 Kovazh, SA 1882 Kovač

- HN Brezje 52 and 76: Pri Kováču [pər ková:č], o" Kovàč [ko'vəč ková:ča], o Kovačíca [kovačíca -e], adj. Kováčov [ková:čou ou] * 1

- HN Češnjevek 29: Pri Kováču [pər ková:č], Ơ Kováč [ková:č -a], O Kovačíca [kovačíca -e], adj. Kováčov [ková:čou -ova -oun] 1

Pri Kovačku $<*$ pri »at« $+* k o v-a-c ̌-b k-b$

- HN Begunje na Gorenjskem 131: Pri Kovačkù [pər kovačkko], ơ Kovačèk [kova'čək -čka], ᄋ Kovačkôva [kovačkó:va -e], adj. Kovačkôv [kovačkó:un -ó:va -ó:un] * SA 1750-1859 Kovazhik, SA 1750-1873 Kovazhik

- HN Koroška Bela, Cesta Ivana Cankarja 14: Pri Kovačkú [pər kovačkọ́:], ơ Kovačkóv [kovačkó:un -ga], Q /, adj. Kovačkóv [kovačkó:ư -ọ́:va -ó:un] * /

Pri Kovačevcu $<*$ pri $»$ at $«+* k o v-a-\check{c}-e v-b c-b$

- HN Bohinjska Češnjica 8: Pri Kovačévcu [pər kovačè̀:uco], ơ Kovačévc [kovačè̀:uc -a], O Kovačévka [kovačẹ̀:unka -e], adj. Kovačév [kovačẹ̀:u -ẹ̀:va -ẹ̀:ü] FK 1827 Kovazhouzh, SA 1831 Kovazheuc, SA 1882 Kovačevc

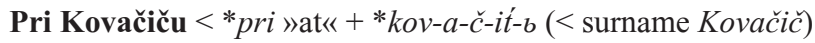

- HN Slovenski Javornik, Pionirska ulica 11: Pri Kováčiču [pər ková:čič], ơ" Kováčič [ková:čič -a], o /, adj. Kováčičev [kováičičou -ova -oun] * ।

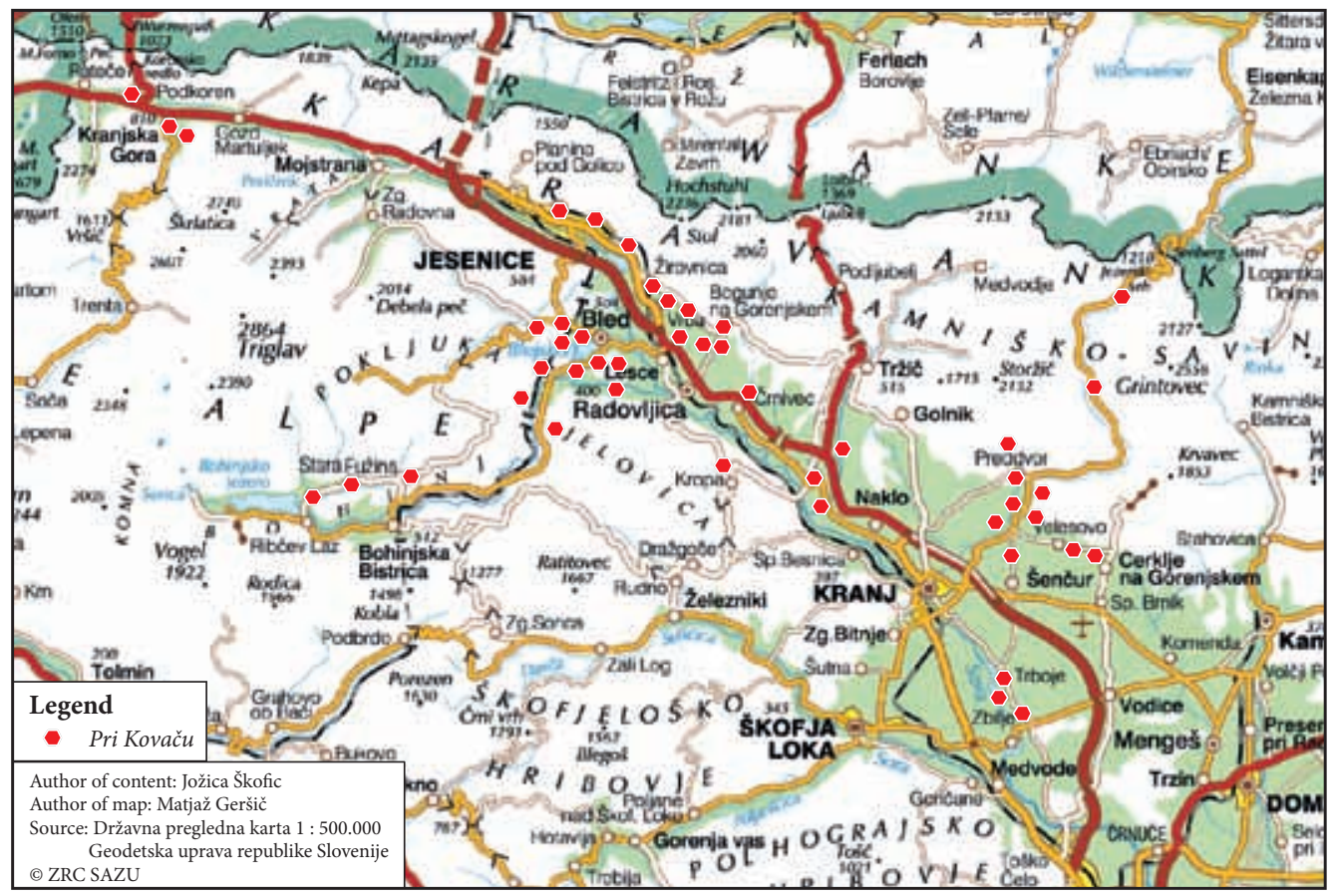

Figure 2: Spatial distribution of the oeconym Pri Kovaču in Upper Carniola. It is interesting that there are no oeconyms motivated by the profession smith (Slov. kovac) in Kropa. Kropa is known for its traditional iron forging and smithies, and almost all of the inhabitants made their living by hammering and blacksmithing, so any naming motivated by this activity would not be useful. 
Pri Kovačijovcu $<*$ pri $\gg$ at « $+* k o v-a-\check{c}-(i j)-o v-b c-b$

- HN Begunje na Gorenjskem 31: Pri Kovačíjovcu [pər kovačírjounc], o" Kovačíjovc [kovačírjouc -a], O Kovačijovka [kovačíjouka -e], adj. Kovačíjev [kovačíjou -ova -ou] * SA 1750-1859 Kovashijouz, SA 1750-1873 Kovashijouz

Na Kovačnici $<* n a » o n \ll+* k o v-a-c ̌-b n-i c-a »$ smithy«

- HN Bohinjska Češnjica 95: Na Kováčnici [na ková:čənce], ơ /, o /, adj. / * /

- HN Jereka 34: Na Kováčnici [na ková:čənc], ơ Kovačičən [kovačìč̌ən] O /, adj. / (s Kováčənce) /

Many of the oeconyms in the Upper Carniola dialect have their origin in male proper names (1030/5450 or $18.9 \%$ ), whereas the percentage of oeconyms originating in female proper names is much lower $(87 / 5450$ or 1.6\%); the most common female proper names are Katra (9), Jera (6), Majda/Magdalena (7), Alenka/Lenka (5), and Johana (5).

The most common male proper names from which Upper Carniolan oeconyms are derived are Jurij (59), Janez (52), Anton (43), Matija (41), Jakob (40), Miha (40), Peter (40), Martin (37), Marko (35), Tomaž (32), Andrej (30), Urban (30), Gregor (30), Blaž (31), Jožef (29), Simon (28), Klemen (27), Luka (24), Jernej (22), Štefan (20), Lovrenc (18), Franc (17), Matevž (16), Pavel (15), and Valentin (14, plus Tine with 10), and the rarest are Adolf, Karl, Maks, Mohor, Metod (all only once), and Ciril (twice).

The most frequent suffixes in oeconyms derived from male proper names are: - $\varnothing$ (e.g., Pri Alešu, Filipu, Luku), -ač (e.g., Pri Mrtnaču, Vožbaču, Jernaču, Milaču), -ak (e.g., Pri Klemenaku), -ček (e.g., Pri Andrejčku, Štefančku, Jančku, Martinčku, Petrčku, Tinčku), -e (e.g., Pri Bvažetu, Anžetu), -ec (e.g., Pri Jakcu, Lukcu, Markcu, Šmoncu, Toncu, Rbancu), -ečman (e.g., Pri Anžečmanu), -ej (e.g., Pri Toneju, Jurčeju, Miheju, Tineju), -ejček (e.g., Pri Tonejčku), -ejovec (e.g., Pri Tonejovcu), -ek (e.g., Pri Pavleku, Anžku, Francku), -elj (e.g., Pri Franceljnu, Gusteljnu, Lojzeljnu, Miheljnu, Vrbanceljnu), -eljc (e.g., Pri Anzeljcu), -eljič (e.g., Pri



Figure 3: The suffix - ač in oeconyms derived from male proper names. 
Markoteljču), -ež (e.g., Pri Matiježu, Pavležu, Tinežu, Vertežu, Učežu), -ežek (e.g., Pri Učešku), -i (e.g., Pri Pepiju, Poldiju; Pri Žanitu), -ic (e.g., Pri Petricu), -ič (e.g., Pri Uriču, Jakobču, Jožefču, Lenarču, Petrču), -iček (e.g., Pri Anžičku), -in (e.g., Pri Gregorinu, Tomažinu), -ko (e.g., Pri Andrejkotu), -kulež (e.g., Pri Anžkuležu), -lin (e.g., Pri Anžlinu, Marklinu), -man (e.g., Pri Jožmanu, Jurmanu, Lešmanu), -nik [-nek] (e.g., Pri Tomažneku, Bvažneku, Jožneku), -ovček (e.g., Pri Udamovčku), -ovec (e.g., Pri Grogorjovcu, Matevžovcu, Mihovcu, Petrovcu), -ovi (e.g., Pri Jakupovih, Jurjovih, Petrovih), -uc (e.g., Pri Štefucu), -uč (e.g., Pri Mrkuču), -ulič (e.g., Pri Bažulču), -un (e.g., Pri Bvažunu, Martunu), and -uš (e.g., Pri Markušu).

Some examples of the lexicographic and cartographic presentation of oeconyms derived from male and female proper names:

Vid- $\rightarrow$ Bid, Bidec, Bisc, Vidic, (Videc) $\leftarrow$ Lat. Vitus (+ Germ. Wido, Witto, Wito)

Pri Bidu < * pri $\gg$ at $\ll+($ Vid $)-b$

- HN Črnivec 26: Pri Bídu [pər bì̀t], ơ Bídove [bì:dou -ga], @/, adj. Bídov [bì̀dou bì̀dova bì:doun * /

Pri Bidcu < * pri $»$ at $\ll+(V i d)-b c-b$

- HN Zgornje Gorje 39: Pri Bídcu [pər bì:sco], ơ Bídec/Bísc [bì:dəc/bì:sc bì:sca], o Bíhka [bì:xka -e], adj. Bíščev [bì:ščou -ova -oun] * FK 1827 Widitz, SA 1759-1877 Vidiz, SA 1790-1905 Vidic (Bisc), Kunstelj 1954 Bidac

- HN Bled, Zagoriška cesta 13: Pri Bídcu/Pri Bíscu [pər bì:sc], ơ" Bídec [bì:dəc bì:sca], o Bíhka [bì:xka -e], adj. Bíščev [bì:ščou -ova -oun] * FK 1827 Widitz, SA 1769-1869 Vidiz

- HN Bled, Partizanska cesta 1: Pri Bídcu [pər bìssco], O" Bídec [bì:dəc bì:sca], o Bíhka [bì:xka -e], adj. Bíščev [bì:ščou -ova -ou] * FK 1827 Widetz, SA 1771-1869 Vidiz, SA 1799-1869 Vidic

- HN Podhom 20: Pri Bíscu [pər bì̀sc], ơ' Bídec [bì̀dec bì̀sca], o Bíhka [bì̀xka -e], adj. Bíščev [Bì:ščou -ova -oun] FK 1827 Widitz, SA 1790-1905 and SA 1900 Vidic, Zupan 1995 Bisc

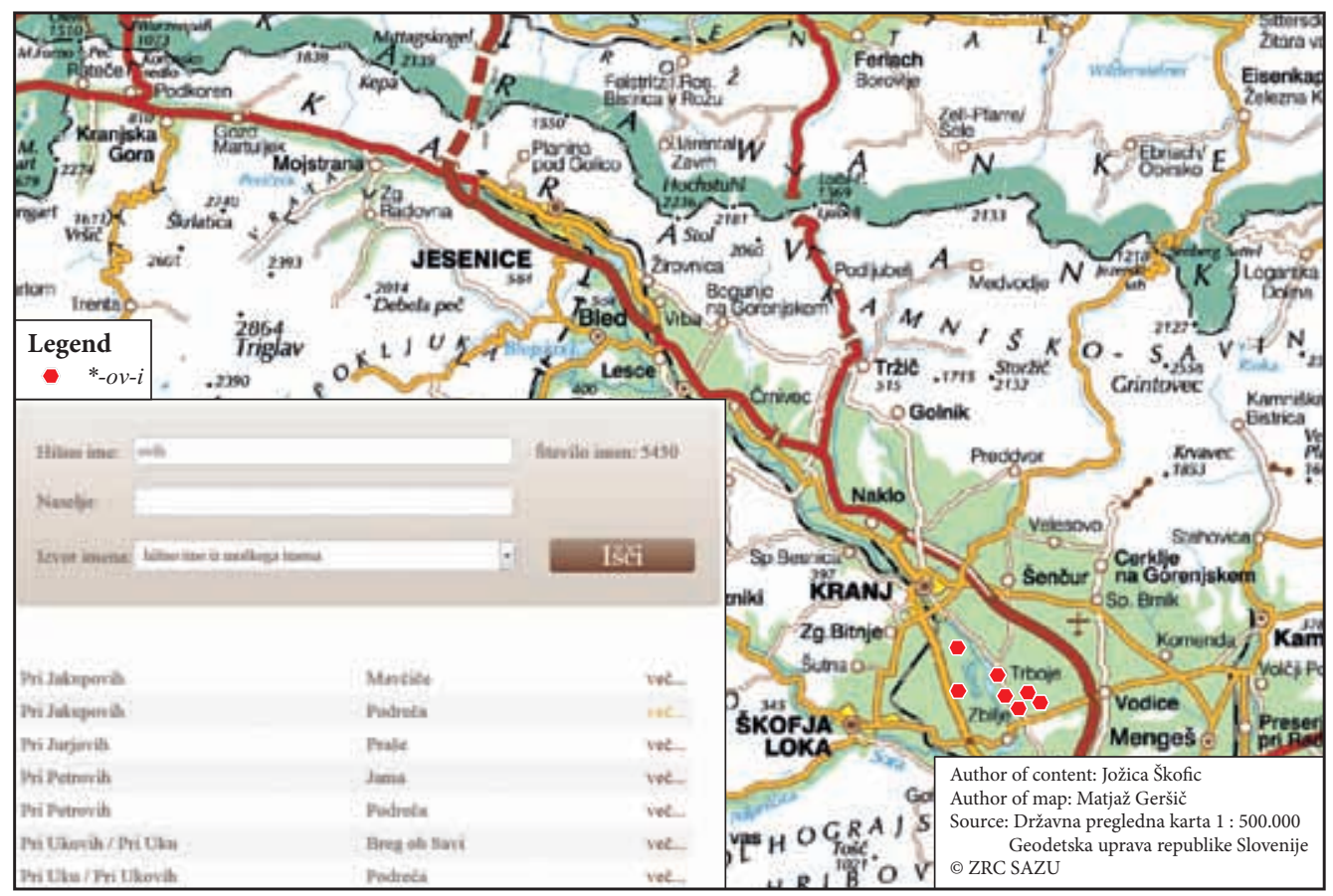

Figure 4: The suffix -ovi in oeconyms derived from male proper names. 
Pri Biscu < * pri »at $«+($ Vid $)-b c-b$

- HN Kamnje 15a: Pri Bíscu [pər bì:sc], ơ Bísc [bì:sc -a], @ Bíhka [bì:xka -e], adj. Bíščev [Bì:ščou -ova -ou] * FK 1827 Widtz, SA 1891 Bisz, SA 1910

- HN Ravne v Bohinju 5: Pri Bíscu [pər bì̀sc], ơ Bísc [bì̀sc -a], o Bíhka [bì̀xka -e], adj. Bíščev [Bì:ščou -ova -oun] \&A 1910 Bisc

Pri Vidicu < *pri »at « + surname Vidic $<($ Vid $)$-bc-b

- HN Srednji Vrh 11: Pri Vídicu [pər vì:dic], ơ Vídic [vi:dic -a], o /, adj. / SA 1903 Vidic

- HN Slovenski Javornik, Terenska ulica 10: Pri Vídicu [pər vì:dic], ơ o" Vídic [vi:dic -a], o /, adj. / * /

Katr- $\Rightarrow$ Katra, Katrnek, Katrnjek, Katerinc, Katračnek, Katrjačnek, Katričnek $\leftarrow$ Katarina $\leftarrow$ (Germ. Catarina $) \leftarrow$ Lat. Caterina $(\leftarrow$ Gr. Aikaterine $)$

Pri Katri $<*$ pri $»$ at $«+*($ Katr $)-a$

- HN Bistrica pri Tržiču 43: Pri Kátri [pər kà:trə], Ơ Kátərən [kà:tərən -ga], @ Kátra [kà:tra -e], adj. Kátrən [kà:trən kà:tərna kà:trən] *

Pri Katrnek <*pri »at« $+*($ Katr $)$-bn-ik-b

- HN Spodnje Gorje 56: Pri Kátrneku [pər kà:tərnek], ơ Kátrnek [kà:tərnek -a], o /, adj. Kátrnekov [kà:tərnekou -ova -oun] Kunstelj 1954 Katrnek

- HN Zgoša 45: Pri Kátrneku [pər kà:tərnek], ơ Kátrnek [kà:tərnek -a], O Kátrnca [kà:tərənca -e], adj. Kátrnekov [kà:tərnekou -ova -ou] * SA 1750-1859 and 1750-1873 Katernjek, Sinobad 1998 Katernek - HN Zvirče 12: Pri Kátrneku [pər kà:tərnek], O" Kátrnek [kà:tərnek -a], @ /, adj. Kátrnekov [kà:tərnekoun -ova -ou] \& SA 1767-1856 (1846) Katernik, SA 1792-1912 (1869) Katernek

Pri Katrnjek $<*$ pri $»$ at $\ll+*(K a t r)-\dot{n}-a k-b$

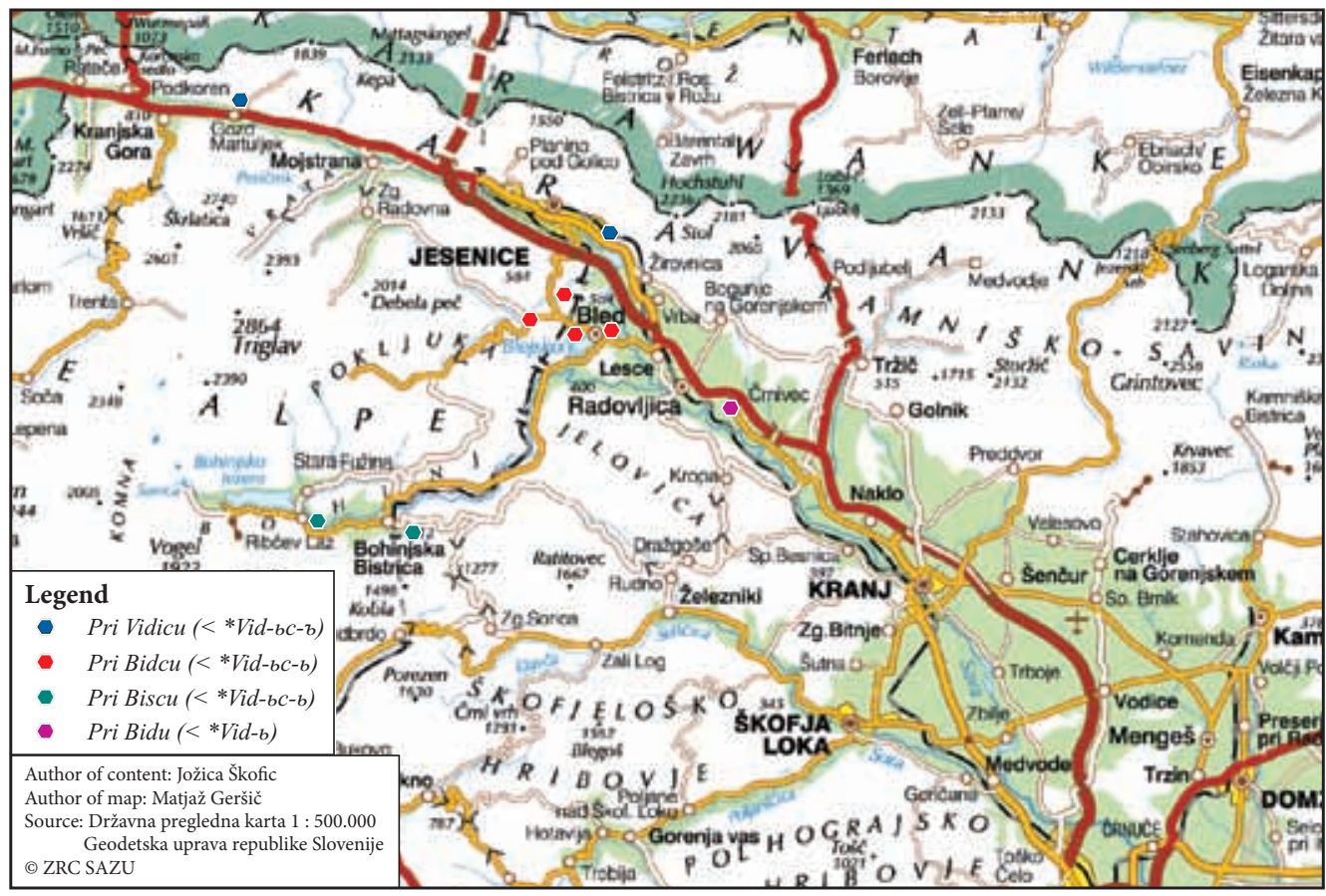

Figure 5: Spatial distribution of the oeconym Pri Vidicu/Pri Vidu/Pri Bidcu/Pri Biscu in Upper Carniola. Phonological variants of oeconyms motivated by the male proper name Vid. 
- HN Studor 38: Pri Kátrnjeku [pər kà:tərnjeko], ơ Kátrnjek [kà:tərnjek -a], \& /, adj. Kátrnjekov [kà:tərnjekou -ova -ou] * FK 1827 Katerneg, SA 1821 Katernek

Pri Katerincu $<*$ pri $»$ at $«+*($ Kater $)-i n-b c-b$

- HN Rateče 66: Pri Kateríncu [pər katerìnc], O" Katerínčnjak [katerìnčnjak -a], @ Katerínca [katerì̀nca -e], adj. Katerínčən [katerì̀nčən -čna -čən] * FK 1827 Cartarinz, SA 1846 Katarinz

Pri Katračneku $<*$ pri »at « + *(Katr)-ač-bn-ik-b ( $\leftarrow$ surname Katrašnik (SA 1900-1910))

- HN Bodešče 7: Pri Katráčneku [pər katrà:čnek], Ơ Katráčnek [katrà:čnek -a], O+ Katráčnica [katrà:čənca -e], adj. Katráčnekov [katrà:čnekou -ova -ou] * SA 1900-1910 Katračnik

Pri Katrjačneku $<*$ pri $»$ at « $+*($ Katr)-j-ač-bn-ik-b (maybe adjectival derivation, like Martin-j-i)

- HN Velesovo 42: Pri Katrjáčneku [pər kətərjà:čnek], O" Katrjáčnek [kətərjà:čnek -a], O Katrjáča [kətərjà:ča -e], adj. Katrjáčnekov [kətərjà:čnekou -ova -oun] * FA 1827 Katerjazhnek, SA 1789-1816 Katriazhnek, SA 1785-1887 (1879) Katerjačnik

Pri Katričneku $<*$ pri $»$ at « + *(Katr)-it́-bn-ik-b

- HN Bohinjska Bela 70: Pri Katríčneku [pər katrì:čnek], Ơ Katríčnek [katrì:čnek -a], O Katríčnca/Katríška [katrì:čənca -e/katrì:ška -e], adj. Katríčnekov [katrì :čnekou -ova -oun] SA 1900-1910 Katričnjek

Jer- $\hookrightarrow$ Jera, Jerca, Jerčnek, Jerčini $\leftarrow$ Gera $\leftarrow$ OHG Gertrud $(\leftarrow$ Lat. Gertrudis $)$

Pri Jeri $<*$ pri $»$ at $«+*(J e r)-a$

- HN Praše 5: Pri Jéri [pər jẹ̀:r], ơ Jérnik [jẹ̀:rnək -a], O Jérnica [jẹ̀:rənca -e], adj. Jérin [jẹ̀:rən -rna -rən] * SA 1907 Stari Zlekar (Pri Jeri)

- HN Rateče 74: Pri Jêri [pər jèrr], ơ Jêrin [jè̀rən -ga], o Jéra [jèrra -e], adj. Jêrin [jèrrən -rna -rən] * / - HN Trstenik 6: Pri Jéri [pər jẹ̀rr], o" Jérnik [jẹ̀rnek -a], O Jéra [jẹ̀ra -e], adj. Jérin [jẹ̀rrən -rna -rən] * / Pri Jerci $<*$ pri $»$ at $\ll+*(J e r)-i c-a$

- HN Prihodi 1: Pri Jérci [pər jẹ̀:rc], ơ Jércən [jẹ̀rrcən -ga], o /, adj. Jércin [jẹ̀:rcən -cna -cən] * /

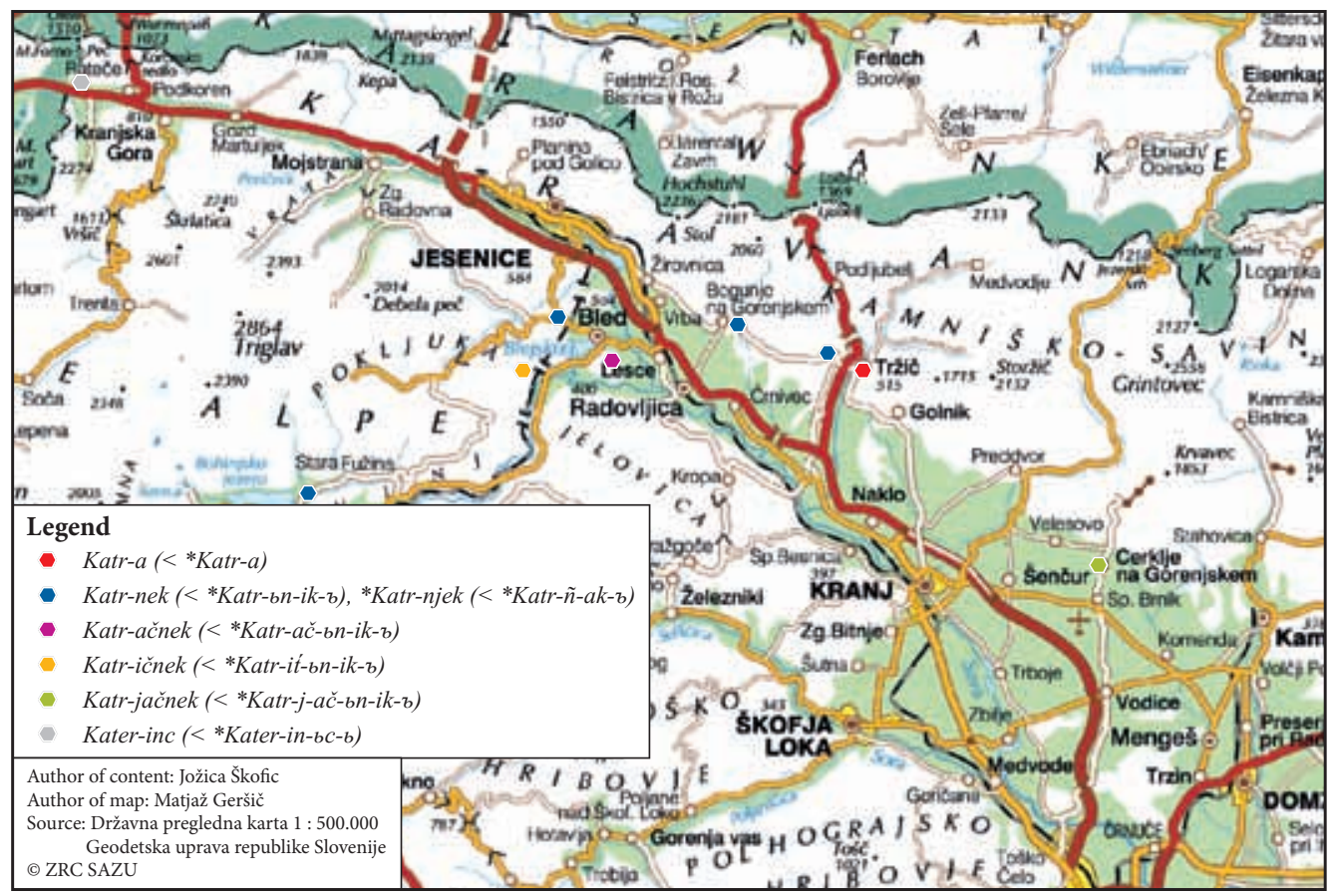

Figure 6: Suffixes of oeconyms derived from the female proper name Katr-a: $-a$, -nek $(<-b n-i k-b),-n j e k(<-n-a k-z),-a c ̌ n e k(<-a c ̌-$ bn-ik-b), -ičnek (<-it́-bn-ik-b), -jačnek (<-j-ač-bn-ik-b), -inec (-in-bc-b) 
Pri Jerčnih $<*$ pri $»$ at « $+*(J e r)-i c ̌-i n-ъ(<J e r-i c-a)$

- HN Podreča 2: Pri Jérčnih [pər jẹ̀:rčnəx], O" Jérčenk [jẹ̀:rčənk -a], O Jérčna [jẹ̀:rčna -e], adj. Jérčin [jẹ̀:rčən -čna -čən]

Pri Jerčneku $<*$ pri $» a t \ll+* J e r-i c ̌-b n-i k-b(<J e r-i c-a)$

- HN Poljšica pri Gorjah 31: Pri Jérčneku [pər jẹ̀rrčneko], O" Jérčnek [jẹ̀:rčnek -a], o /, adj. Jérčnekov [jẹ̀:rčnekou -ova -ou]] * SA 1900 Pri Jeri, Kunstelj 1954 Jernek

Pri Jeriču $<*$ pri »at« + *Jer-it́-b

- HN Bašelj 5: Pri Jeríču [pər jerí:č], O" Jerič [je'rəč jerí:ča], O Jeríčka [jerì:ška -e], adj. Jeríčov [jerí:čou -ova -ou] * FK 1827 Jeretsch, SA 1771 Jerezh, SA 1880 Jerič

- HN Spodnje Gorje 11: Pri Jeríču [pər jerí:čo], O" Jerìč [je'rəč jerí:ča], o Jeríčka [jerì̀ška -e], adj. Jeríčov [jerí:čou -ova -oun] * FK 1827 Jerizh, SA 1771 1759-1877 (1836) Jerizh, SA 1790-1905 Jerič

\section{Conclusion}

Microtoponyms, and especially oeconyms, are an important part of national cultural heritage and are interesting not only to their local users but also to various disciplines: geography, history, ethnology, and linguistics. One can study various connections between the linguistic viewpoints on the toponyms presented in this article and the geographical locations in a specific area. Geographical and historical data about named places can help linguists understand naming motivations and, vice versa, linguistic information can help geographers understand how toponyms have developed through time. From the linguistic point of view, the recorded dialect form of oeconyms and microtoponyms is especially valuable because it provides information about the pronunciation, inflection, and historical development of a language and its local dialects. Proper names can be compared to common nouns (synchronically and diachronically) and presented in a specially designed dictionary of toponyms as well as geolinguistically on maps. This article offers some solutions for such presentations of these toponyms.

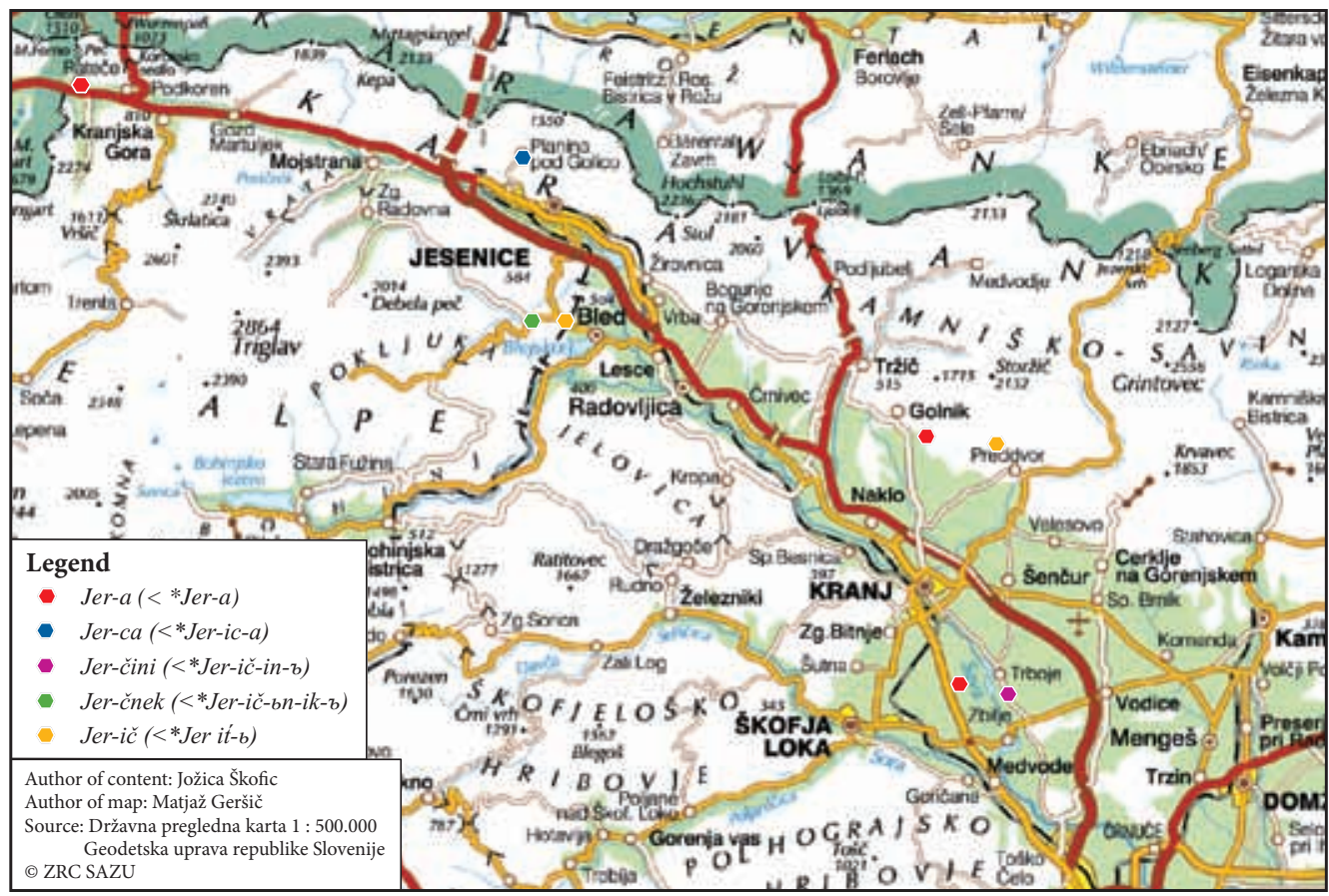

Figure 7: Suffixes of oeconyms derived from the female proper name Jer- $a:-a,-c a(<-i c-a),-\check{c}-i n-i(<-i c ̌-i n-b),-\check{c}$-nek $(<-i \check{c}-b n-$ $i k-b),-i \check{c}(<-i \dot{t}-b)$ 


\section{References}

Čop, D. 2007: Imenoslovje in etimologija imen. Jezikoslovni zapiski 13, 1-2.

Furlan, M., Gložančev, A., Šivic-Dular, A. 2000: Pravopisna ustreznost zapisa lastnoimenskega gradiva v Registru zemljepisnih imen in Registru prostorskih enot. Geografski vestnik 80-1.

Internet 1: http://www.ledinskaimena.si/ (31.8.2016).

Keber, J. 2002: Rojstna imena, hišna imena, vzdevki, psevdonimi v Sloveniji. Jezikoslovni zapiski 8-2.

Kenda-Jež, K. 2016: Fonetična transkripcija. Slovenski lingvistični atlas - SLA 2.2 Atlas. Ljubljana.

Klinar, K. 2011: Kako se pri vas reče? Hišna imena v naseljih Breznica, Doslovče, Rodine, Smokuč in Vrba. Žirovnica.

Klinar, K. 2013: Hišna imena na Gorenjskem. Jesenice. Internet: http://www.hisnaimena.si/ (31. 8. 2016).

Klinar, K., Geršič, M. 2014: Traditional house names as part of cultural heritage. Acta geographica Slovenica 54-2. DOI: http://dx.doi.org/10.3986/AGS54409

Klinar, K., Škofic, J. 2015a: Ledinska imena v občini Jesenice. Jesenice.

Klinar, K., Škofic, J. 2015b: Ledinska imena v občini Kranjska Gora. Jesenice.

Klinar, K., Škofic, J. 2015c: Ledinska imena v občini Tržič. Jesenice.

Klinar, K., Škofic, J., Šekli, M., Piko-Rustia, M. 2012: Metode zbiranja hišnih in ledinskih imen: Projekt FLU-LED v okviru Operativnega programa Slovenija-Avstrija 2007-2013. Jesenice, Celovec.

Merkù, P. 1993: Svetniki v slovenskem imenoslovju. Trst.

Parish records - Status animarum, 1750-1950. Škofijski arhiv Ljubljana.

Protocols for Emperor Francis I. cadastre, 1823-1869 for Kranjska/Carniola (Arhiv RS, SI AS 176) and Koroška/Carinthia (Arhiv RS, SI AS 178). Ljubljana.

Snoj, M. 2009: Etimološki slovar slovenskih zemljepisnih imen. Ljubljana.

Šekli, M. 2008: Zemljepisna in osebna lastna imena v kraju Livek in njegovi okolici. Linguistica et philologica 22. Ljubljana.

Šivic-Dular, A. 1988: Temeljna načela pri pisanju slovenskih zemljepisnih imen. Jezik in slovstvo 34, 1-2.

Škofic, J. 2001: Hišna imena v Kropi. Simpozij Slovenska lastnoimenskost: zbornik s simpozija '99 v Pišecah. Novo mesto.

Škofic, J. 2007: Narečno besedilo kot vir za imenoslovno raziskavo. Jezikoslovni zapiski 13-1/2.

Škofic, J. 2009: Zemljepisna lastna imena med narečjem in knjižnim jezikom. Slovenska narečja med sistemom in rabo. Obdobja, Metode in zvrsti 26. Ljubljana.

Škofic, J. 2011: Kako se pri vas reče (in kako se to napiše)? Izzivi sodobnega slovenskega slovaropisja. Zora 75.

Škofic, J. 2013: Zasnova slovarja narečnih hišnih in ledinskih imen. Slavistika v regijah. Ljubljana.

Škofic, J. 2014: Zasnova vseslovenskega slovarja narečnih hišnih in ledinskih imen. Annales, Series historia et sociologia 24-2.

Škofic, J. 2016: Predložna ledinska imena v gorenjskem narečju. Rojena v narečje: akademikinji prof. dr. Zinki Zorko ob 80-letnici. Maribor. 